\title{
RBFOX1 wt Allele
}

National Cancer Institute

\section{Source}

National Cancer Institute. RBFOX1 wt Allele. NCI Thesaurus. Code C98195.

Human RBFOX1 wild-type allele is located in the vicinity of 16p13.3 and is approximately $1694 \mathrm{~kb}$ in length. This allele, which encodes RNA binding protein fox-1 homolog 1 , is involved in the regulation of mRNA processing. 